\title{
サツマイモ葉凍結乾燥粉末配合パンの製パン性と品質
}

\author{
鈴野弘子* ·石田 裕* ·印南 敏** ·前川昭男**・田所忠弘**
}

（*東京農業大学短期大学部，**東京農業大学応用生物科学部）

\section{Bread-making properties and quality of bread containing a freeze-drying powder of sweet potato leaves}

\section{Hiroko Suzuno*, Hiroshi Ishida*, Satoshi Innami**, Akio Maekawa**, Tadahiro Tadokoro**}

* Junior College of Tokyo University of Agriculture, 1-1-1, Sakuragaoka, Setagaya-ku, Tokyo, 156-8502

**Faculty of Applied Bioscience, Tokyo University of Agriculture, 1-1-1, Sakuragaoka, Setagaya-ku, Tokyo, 156-8502

\author{
*下156-8502 東京都世田谷区桜丘 1-1-1 \\ **テ156-8502 東京都世田谷区桜丘 1-1-1
}

The purpose of this study was to evaluate the usefulness of sweet potato leaves as a food supply source. We prepared bread containing a freeze-drying powder of sweet potato leaves, and evaluated its bread-making properties and quality.

Farinograms of strong flour containing a freeze-drying powder of sweet potato leaves showed a decrease in stability by mixing. However, the expansion ability of the dough of bread containing this powder slightly improved. There was no other problem in bread-making properties.

Bread containing a freeze-drying powder of sweet potato leaves showed a volume, water content, degree of starch gelatinization, and bread hardness similar to those of bread not containing this powder, but was slightly inferior to bread containing a dry powder of Jew's marrow leaves in terms of brightness. Analytic sensory tests revealed similar results between bread containing a freeze-drying powder of sweet potato leaves and that containing a dry powder of Jew's marrow leaves. Taste sensory tests showed no significant difference in any item other than brightness of color between breads containing and not containing a freeze-drying powder of sweet potato leaves. Therefore, the quality of bread containing a freeze-drying powder of sweet potato leaves was considered to be good.

Since addition of a freeze-drying powder of sweet potato leaves increases food fiber, carotene, calcium, and polyphenol, the functional value of bread may improve.

\section{緒言}

サツマイモ (Ipomoea batatas Poir.) は，ヒルガオ科 の植物である。農林水産省統計によると我が国の平成14 年のサツマイモ収穫量は，103万トンであった。

現在，日本でのサッマイモの利用は，塊根をデンプン 等の加工原料用, あるいは直接調理するのが一般的で葉 や葉柄部分を食用にすることは少ない。すなわち，葉や 葉柄部は塊根部と同様に生産はあるが，そのほとんどは
利用されていない。しかし，東南アジアや台湾などの亜 熱帯や熱帯地方では，サツマイモの葉や葉柄を日常的に 食し ${ }^{1,2)}$, これらの地域では葉や葉柄部にアク成分や毛 茸の少ない専用品種が発達している。近年, サッマイモ の葉や葉柄部には, ビタミン類, ミネラル類, ポリフェ ノール，食物繊維が豊富に含まれていることが明らかに されている3 6)。その機能性としては，ラットの肝臓コ レステロール濃度を低下させること ${ }^{7,8)}$ や葉部熱水抽出 物に高いラジカル消去活性を有すること帛が報告されて 
いる。このようにサツマイモの葉および葉柄は, 機能性 成分含有の未利用資源として注目され，サッマイモ葉の 粉末化 ${ }^{10)}$ や飲料の開発11) も行われている。筆者らも，サ ツマイモ葉の有効利用を図る目的で葉の乾燥粉末を加え たクッキーを調製し，その品質を検査したところ，非常 に良好であり, サッマイモ葉は食品の加工に利用するこ とができる新規素材であることを認めた ${ }^{12) 。 ~}$

他方，日常よく食するパンは，ビタミン類をほとんど 含んでおらず，食物繊維量も極めて少ない。パンは主食 として用いられることが多く，食する量や回数が多いた め,これらのパンに機能性を持ち合わせた食材を添加す ることにより，簡便かつ手軽にそれらの摂取が可能とな ると共に，健康の維持・増進に資することになる。この ような考えのもと, 近年, 機能性を持ち合わせた食材を 添加した機能性パンの開発が進んでいる13 16)。

そこで, 本研究では, サッマイモ葉を凍結乾燥粉末化 して小麦粉に添加し，パンを調製して，その製パン性と 品質について検討した。なお，サッマイモ葉と同様に， 葉に粘りを有し，栄養価の高い野菜として評価されてい るモロヘイヤ葉乾燥粉末添加パンも調製し, 比較検討し た。

\section{実験方法}

\section{1. 試 料}

サツマイモ葉 (コガネセンガン: 神奈川県産) は, 1998 年 8 月に採取し, 凍結乾燥後, 100 メッシュに粉砕し, オートクレーブで滅菌して用いた。対照としたモロへイ ヤ葉 (山口県産) は, 1997年 $9 \sim 10$ 月に採取し, $70^{\circ} \mathrm{C}$ で 14時間乾燥して，100メッシュに粉砕したもの（アルソ ア央粧秼製）を入手し，オートクレーブで隇菌して用い た。

\section{2. 材料および製パン条件}

パンの原材料には, 強力粉（カメリヤ, 日清製粉), バター（ケーキ用マーガリン, 雪印乳業), 砂糖（テー ブルシュガー, 日新製糖), 塩（高純度家庭用精製塩, 塩事業センター), 脱脂粉乳 (スキムミルク, 雪印乳業), ドライイースト（顆粒状カメリヤイースト，日清製粉） を用いた。

配合割合は, 一般的な食パンの基本配合に準じ, 強力 粉 $300 \mathrm{~g}$, 塩 $6 \mathrm{~g}$, 砂糖 $15 \mathrm{~g}$, バター $15 \mathrm{~g}$, スキムミルク $15 \mathrm{~g}$, ドライイースト $6 \mathrm{~g}$, 水 $195 \mathrm{~g}$ とした。サッマイモ 葉凍結乾燥粉末およびモロへイヤ乾燥粉末の添加は, 予 備実験の結果より, 強力粉に対して無水物換算で $2 \%$ を 代替した。

これらの材料を配合して，パン用ミキサー（レディー スミキサー，大正電気(侏) で10分間攪拌後，40分間発酵 （温度 $34^{\circ} \mathrm{C}$, 湿度 $85 \%$ ）させた。次にガス抜きし，さら に20分間発酵, ベンチタイムを10分間設け, 成形した。 その後, 二次発酵（温度 $34^{\circ} \mathrm{C}$, 湿度 $85 \%$ ) させてから $180^{\circ} \mathrm{C}$ で30分間焙焼した。

\section{3. 生地の特性}

1）ファリノグラフによる生地の測定 生地の物 性をファリノグラフ（B.U.500, Brabender 社製）で測 定した。強力粉 $40 \mathrm{~g}$ (試料乾燥粉末分は差し引く), サ ツマイモ葉凍結乾燥粉末およびモロヘイヤ葉乾燥粉末は

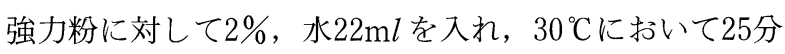
間混ねつし，その間の粘度を自記させた。

2 ）パン生地の膨張力の測定林生地の膨張率 は，イースト工業会法17)を参考に行った。すなわち， 1 リットルのビーカーに捏ね上げたパン生地 $250 \mathrm{~g}$ を底に 密着させて表面が平らになるように詰め, 温度 $37^{\circ} \mathrm{C}$, 湿 度 $80 \%$ の条件の恒温室に入れ，0.5，1，2，3 時間後 の生地の高さを測定し, 元の高さに対しての膨張割合を 求めた。

\section{4. パンの品質評価}

1) 体積, 比容積, 水分, 色調の測定 焼き上が りのパンの体積は, なたね置換法によって求め, さらに 体積を重量で除して比容積を求めた。パン内相部の水分 含有量は常法によって測定した。色調は, 色彩色差計 (CM-200，ミノルタ侏製）を用いて， $L^{*} ， a^{*}, b^{*}$ 值を 測定した。

2 ）官能検査東京農業大学短期大学部栄養学科 男女学生 24 名をパネルとして, サツマイモ葉凍結乾燥粉 末およびモロへイヤ葉乾燥粉末添加パンと無添加パンに ついて，セマンティック・デファレンシャル法により， 分析型および嗜好型官能検査を行った。パンは焙焼24時 間後のものを用いた。分析型官能検査の評価項目は，パ ンの特徵を表わすと思われる外観, 内相の状態, 香り, テクスチャー, 味に関する 13 項目を設定した。嗜好型官 能検査の評価項目は, 分析型官能検査の評価項目に総合 評価を加え14項目とした。

3） パンの組織構造の観察パン内相部の断面組 織をデジタルマイクロスコープ（VH-8000, 侏キーエ ンス製）で観察した。

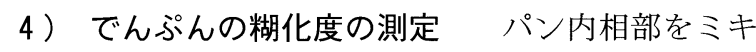
サーで粉砕し，アセトンで脱水したものを糊化度測定用 の試料とした。糊化度は $\beta$-アミラーゼ法 (BAP 法) ${ }^{18)}$ によって測定した。

5 ）硬さの測定パンは焙焼後, ポリプロピレン 製の袋に 24 時間保存し, クリープメータ（RE2$33005 \mathrm{~S}$ : (侏山電製) を用いて破断強度試験を行い, 応 カーひずみ曲線を得た。測定条件は, プランジャー： $40 \mathrm{~mm} \phi$, 圧縮速度 : $1 \mathrm{~mm} / \mathrm{s}$, 圧縮率 $80 \%$ とした。この 応力一ひずみ曲線には破断点が認められなかったため, ひずみ $60 \%$ 時の応力を硬さとして比較した。

\section{結果および考察}

\section{1. 製パン性に及ぼすサツマイモ葉凍結乾燥粉末添加の 影響}

1) 生地の物理特性２％サツマイモ葉凍結乾燥 
〔論文〕サツマイモ葉凍結乾燥粉末配合パンの製パン性と品質

粉末を添加した時の生地の物性をファリノグラフで測定

し，その結果を図 1 に示した。

無添加の場合は，一般的な強力粉のファリノグラムを 示し, 最高粘度に達した後も粘度は低下せず，生地の安 定性は良好であった。これに対し, サッマイモ葉凍結乾 燥粉末およびモロヘイヤ葉乾燥粉末を添加すると, 最高 粘度を示したのち, 混ねつ時間の経過とともにブレーク ダウンが観察された。無添加の場合, 生地が安定してい た時間は17分であったが，サツマイモ葉凍結乾燥粉末添
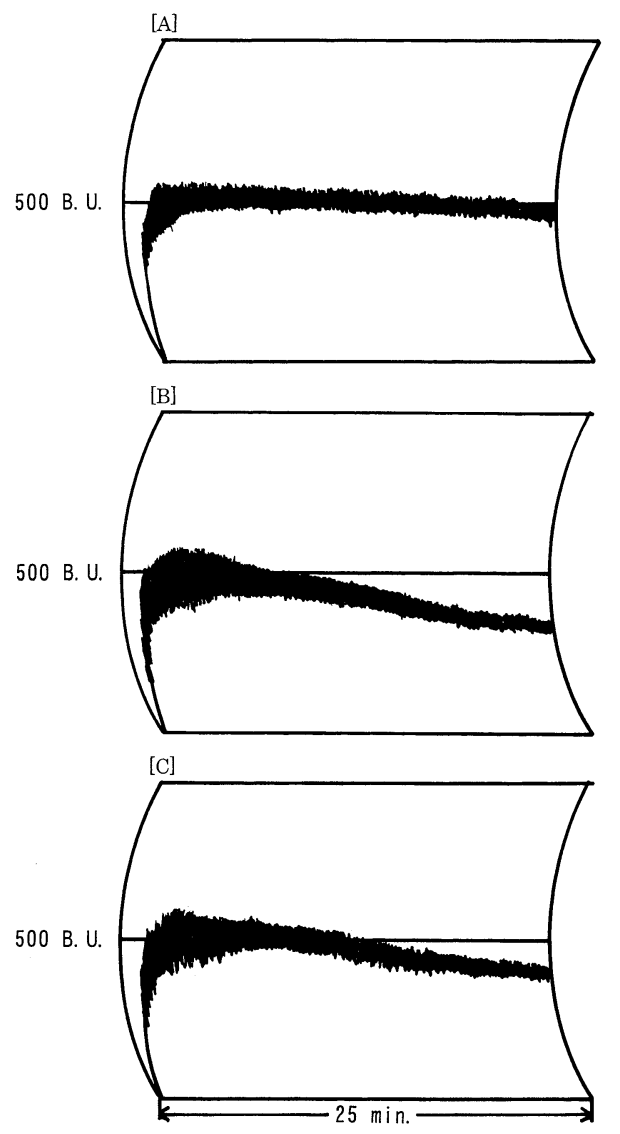

Fig. 1 Brabender farinograms of wheat flour added with or without green leaf powders [A] :None (without green leaf powder), [B] :Wheat flour added sweet potato leaf powder, [C] :Wheat flour added Jew's marrow leaf powder. Added dry green leaf powders were $2 \%(\mathrm{w} / \mathrm{w})$ of wheat flour.

加は6.5分，モロヘイヤ葉乾燥粉末添加は11.0分であり， サツマイモ葉凍結乾燥粉末添加が顕著に安定性が低くな ることが認められた。

生地のブレークダウンは，たんぱく質中の S-S 結合 の切断やたんぱく質の水分保持力の変化，パン生地中の 遊離水の増加などの原因が考えられている ${ }^{17)}$ 。緑葉乾燥 粉末添加生地のブレークダウンの原因は，小麦粉の $2 \%$ 分をそれに代替したため, 無添加生地に比ベグルテン量
が減っていることやサツマイモ葉凍結乾燥粉末およびモ ロヘイヤ葉乾燥粉末中に含まれている水溶性食物緎維が グルテン集合体の内部の水分を奪い，グルテン形成を阻 害したことにあると考えられた。

この結果からサッマイモ葉凍結乾燥粉末およびモロへ イヤ葉乾燥粉末を添加したパン生地のミキシングは, 無 添加より短時間に終了させた方が望むしいと考えられた。 また，葉に粘りがあるなど同様の性質を示す緑葉であっ ても, モロヘイヤ葉乾燥粉末の添加に比べ, サッマイモ 葉凍結乾燥粉末添加の安定性が低加たことは, 含有さ れる食物繊維の粘度や保水性の違いが考えられるが，こ の点については現在検討中である。

2 ）パン生地の膨張力 サッマイモ葉凍結乾燥粉 末添加パン生地の膨張割合を求め，表 1 に示した。

Table 1 Expansion coefficient of bread dough added with or without green leaf powders during storage times

$(\mathrm{cm} / \mathrm{cm})$

\begin{tabular}{cccc}
\hline \multirow{2}{*}{ Storage time ${ }^{*}(\mathrm{~h})$} & \multicolumn{3}{c}{ Kinds of bread dough } \\
\cline { 3 - 4 } & None & Sweet potato leaf & $\begin{array}{c}\text { Jew's marrow } \\
\text { leaf }\end{array}$ \\
\hline 0.5 & $2.2 \pm 0.4$ & $2.3 \pm 0.2$ & $2.3 \pm 0.1$ \\
1 & $3.4 \pm 0.2$ & $3.8 \pm 0.2$ & $3.7 \pm 0.2$ \\
2 & $3.8 \pm 0.6$ & $4.0 \pm 0.2$ & $3.9 \pm 0.1$ \\
3 & $3.9 \pm 0.7$ & $3.9 \pm 0.2$ & $3.7 \pm 0.2$ \\
\hline
\end{tabular}

* : Stored at $37^{\circ} \mathrm{C}$. Added dry green leaf powders were $2 \%(\mathrm{w} / \mathrm{w})$ of wheat flour.

いずれのパン生地も発酵0.5時間では, 元の高さの 2.2 〜2.3倍であり，顕著な差は認められなかった。しかし， 1時間後にサッマイモ葉凍結乾燥粉末添加パン生地の膨 張割合は3.8倍, モロへイヤ葉乾燥粉末添加は3.7倍にな り, 無添加の3.4倍に比べ若干高くなり, 以後 3 時間ま でその割合はほぼ変わらなかった。無添加パン生地も 3 時間後に膨張割合が3.9倍となって, サッマイモ葉凍結 乾燥粉末抢よびモロヘイヤ葉乾燥粉末添加と同程度にな った。サツマイモ葉凍結乾燥粉末およびモロヘイヤ葉乾 燥粉末添加パン生地の膨張が速かったのは, ファリノグ ラフ測定で示されたように生地が無添加より速く脆弱化 し，生地の伸展性を増加させたためと考えられた。

2. パンの品質に及ぼすサツマイモ葉凍結乾燥粉末添加 の影響

1）パンの品質特性 サッマイモ葉凍結乾燥粉末 添加パンの体積, 比容積, 内相部の水分含有量, 色調を 表 2 に示した。

パンの体積, 比容積, 内相の水分含有量は, いずれの パンも顕著な差は認められず，これらの品質にはサッマ イモ葉凍結乾燥粉末およびモロヘイヤ葉乾燥粉末添加は 影響を及ぼさないことがわかった。内相部の色調では, $L^{*}$ 值はモロヘイヤ葉乾燥粉末添加パンに比ベ，サッマ 
日本食生活学会誌 Vol.15 No.1（2004）

Table 2 Quality characteristics of breads added with or without green leaf powders

\begin{tabular}{ccccccc}
\hline \multirow{2}{*}{ Kinds of bread } & Loaf volume $(\mathrm{m} l)$ & Specific loaf volume $(\mathrm{m} l / \mathrm{g})$ & Water $(\%)$ & \multicolumn{3}{c}{ Color } \\
\cline { 5 - 6 } & & & & $L^{*}$ & $a^{*}$ & $b^{*}$ \\
\hline None & $1815 \pm 84$ & $4.91 \pm 0.08$ & $44.0 \pm 0.28$ & 80.3 & -2.2 & 12.5 \\
Sweet potato leaf & $1830 \pm 93$ & $4.87 \pm 0.03$ & $43.3 \pm 0.40$ & 58.4 & -4.4 & 24.3 \\
Jew's marrow leaf & $1843 \pm 75$ & $4.86 \pm 0.05$ & $43.9 \pm 0.07$ & 62.2 & -3.7 & 21.5 \\
\hline
\end{tabular}

$L^{*}, a^{*}, b^{*}$ :Each values was measured by a spectra-colorimeter.
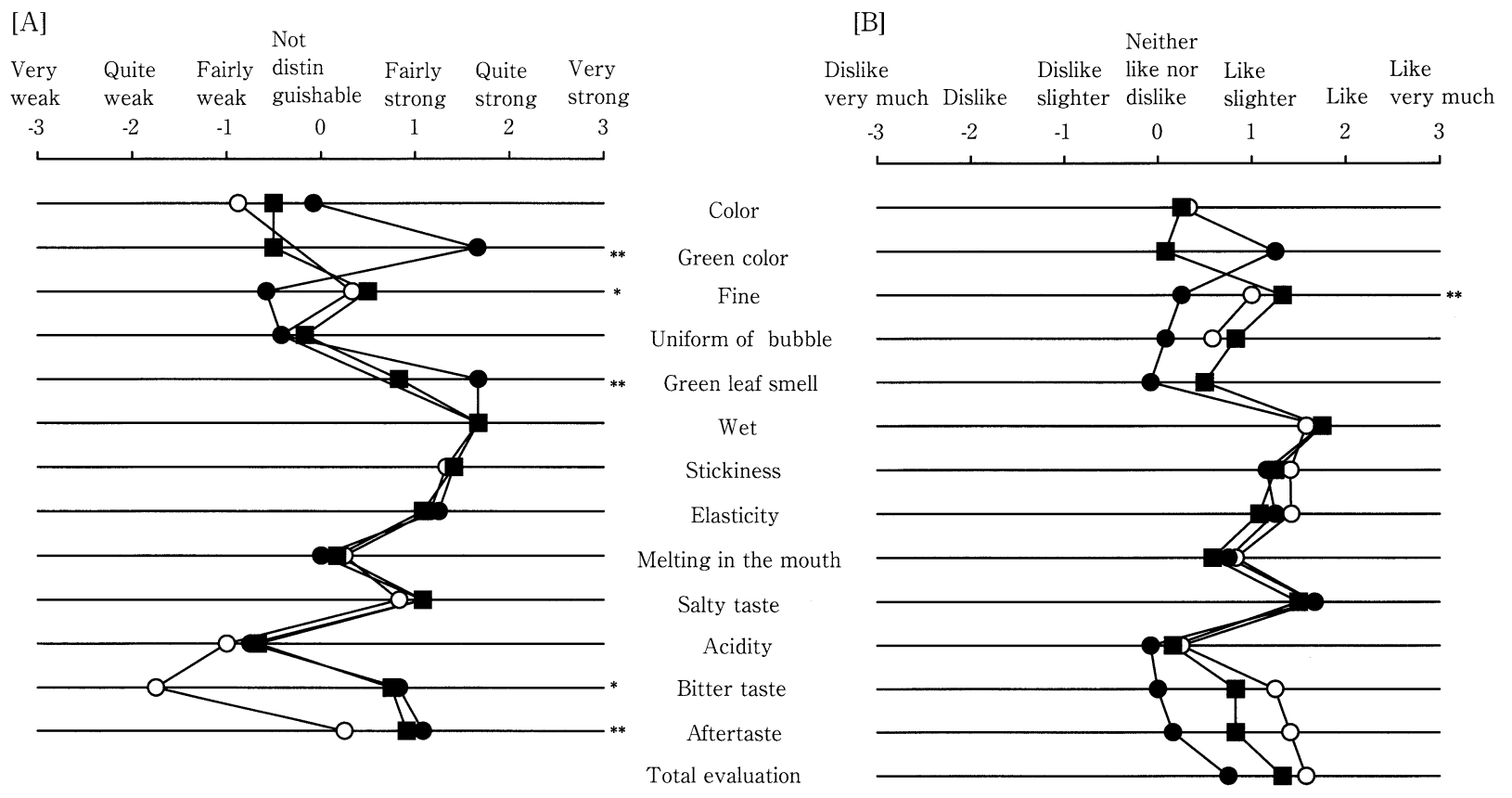

Fig. 2 Sensory evaluations on breads added with or without green leaf powders

[A] : Evaluation of strengths. [B] : Evaluation of likeability. $\bigcirc$, control bread (without green leaf powder); , bread added sweet potato leaf powder; $\mathbf{\square}$, bread added Jew's marrow leaf powder. Added dry green leaf powders were $2 \%(\mathrm{w} / \mathrm{w})$ of wheat flour.

${ }^{*},{ }^{* *}$ Significant difference by two dimensional analysis of variance were $p<0.05$ and $p<0.01$, respectively $(\mathrm{n}=24)$.

イモ葉凍結乾燥粉末添加パンが小さく，やや暗かった。 また， $a^{*}$ 值はモロへイヤ葉乾燥粉末添加パンに比べ, サツマイモ葉凍結乾燥粉末添加パンがマイナスの度合い が大きいことから，緑色が強いということがわかった。 このようにサツマイモ葉凍結乾燥粉末添加パンがモロへ イヤ葉乾燥粉末添加パンより緑色が濃かったのは, サツ マイモ葉凍結乾燥粉末にクロロフィルが多かったことに 起因する。これはクッキーに両乾燥粉末をそれぞれ添加 したときの色調の違いと同様であった ${ }^{12) 。 ~}$

2 ）食味特性 サッマイモ葉凍結乾燥粉末および モロヘイヤ葉乾燥粉末添加パンと無添加パンの官能検査 の結果を図 2 に示した。

分析型官能検査（図 2 A) では, サッマイモ葉凍結乾 燥粉末添加パンは, 苦味, 後味が強いと評価された。ま た, モロヘイヤ葉乾燥粉末添加パンと比較すると, 緑色 が強く, 色のさえがなく, 青臭いと評価されたが, その 他の項目は有意な差は認められず, 両者は近似した評価 であった。さらに, テクスチャーに関する項目は, 無添
加パンの評価と有意な差がなかったことから，サツマイ モ葉凍結乾燥粉末およびモロヘイヤ葉乾燥粉末 $2 \%$ の添 加は，口の中で感じられるほどのテクスチャーに影響を 与えないことが示された。

嗜好型官能検査の結果（図 2 B）では, サツマイモ葉 凍結乾燥粉末添加パンは, 無添加とモロヘイヤ葉乾燥粉 末添加パンに比べ，色のさえは好まれないものの，他の 項目については有意な差が認められなかった。

このことから，サツマイモ葉凍結乾燥粉末添加パンは, 通常の食事に充分に受け入れられるものと判断した。図 表には示していないが，アンケートによるイメージ調査 では, サツマイモ葉凍結乾燥粉末添加パンはモロヘイヤ 葉乾燥粉末添加パンと同様, 健康的なイメージであると 評価された。また，すでに報告したサッマイモ葉凍結乾 燥粉末中の成分值 4 )を用いて, サツマイモ葉凍結乾燥粉 末を $2 \%$ 添加したパン $100 \mathrm{~g}$ 中の食物繊維, カロテン, カ ルシウム, ポリフェノールを算出すると, それぞれ $2.8 \mathrm{~g}, 49 \mu \mathrm{g}, 87 \mathrm{mg}, 11 \mathrm{mg}$ であった。したがって，こ 
〔論文〕サツマイモ葉凍結乾燥粉末配合パンの製パン性と品質

Table 3 Degree of gelatinization and hardness of breads added with or without green leaf powders during storage times

\begin{tabular}{ccccc}
\hline \multirow{2}{*}{ Kinds of bread } & \multicolumn{2}{c}{ Degree of gelatinization $(\%)$} & & Hardness $\left(\mathrm{Pa} \times 10^{3}\right)$ \\
\cline { 2 - 3 } & \multicolumn{2}{c}{ Storage* $(\mathrm{h})$} & 72 & Storage $^{*}(\mathrm{~h})$ \\
\cline { 2 - 3 } None & $62.2 \pm 2.33$ & $34.4 \pm 2.21$ & \\
Sweet potato leaf & $68.9 \pm 5.37$ & $34.8 \pm 0.36$ & & $6.65 \pm 1.09$ \\
Jew's marrow leaf & $63.2 \pm 1.89$ & $33.7 \pm 1.86$ & & $6.47 \pm 0.95$ \\
\hline
\end{tabular}

$*$ : Stored at $20^{\circ} \mathrm{C}$. Added dry green leaf powders were $2 \%(\mathrm{w} / \mathrm{w})$ of wheat flour.
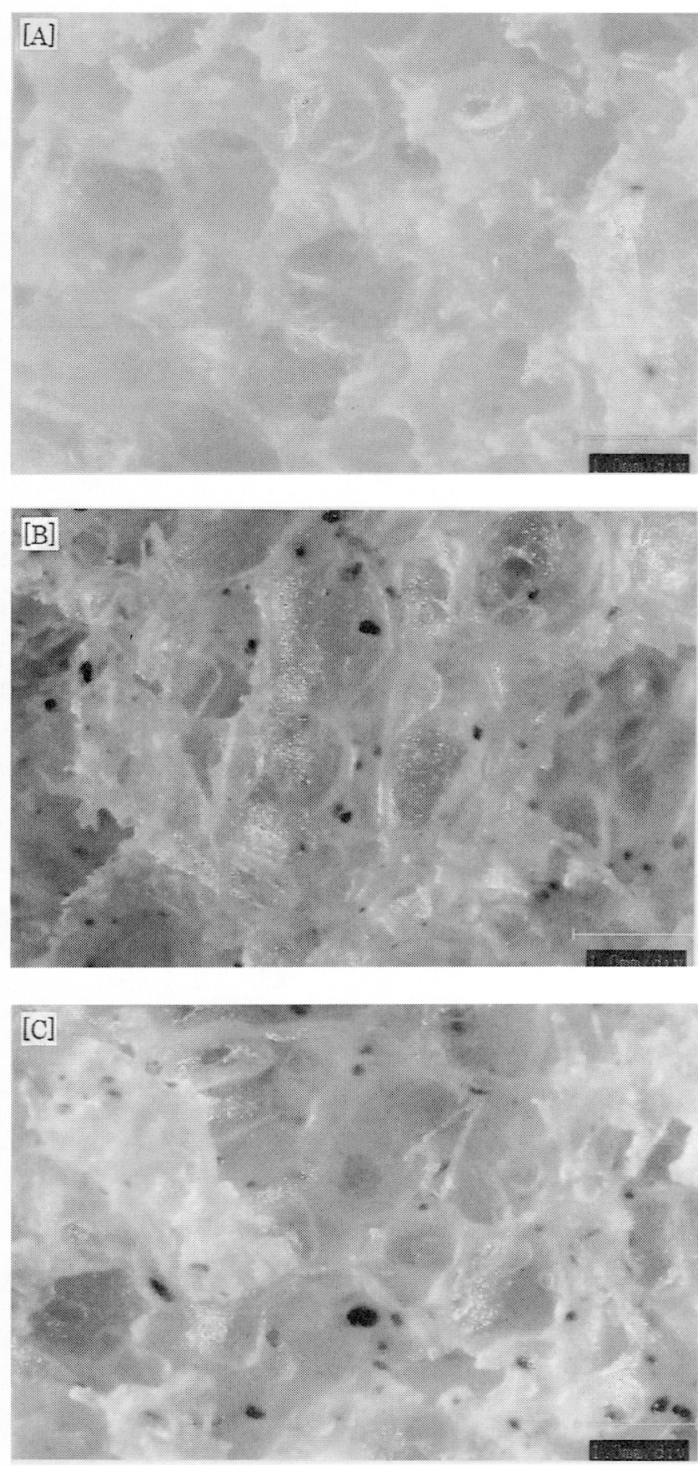

Fig. 3 Digital micrographs of breads added with or without green leaf powders

[A] :None (without green leaf powder), [B] :Bread added sweet potato leaf powder, $[\mathrm{C}]$ :Bread added Jew's marrow leaf powder. Added dry green leaf powders were $2 \%(\mathrm{w} /$ w) of wheat flour.
のパンを $100 \mathrm{~g}$ 食べるとこの量を摂取できることになる ため, 機能性成分の補足的な給源として有効であると思 われた。

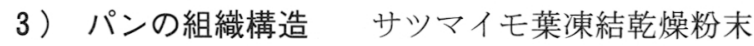
添加およびモロへイヤ葉乾燥粉末添加パンと無添加パン の断面組織を図 3 に示した。

通常，パンは膨張段階で気泡が大きくなるにつれ，グ ルテン膜は薄く伸びると報告されている19)。断面組織の 観察では，無添加パンは明確な気泡を形成しているのに 対して, サッマイモ葉凍結乾燥粉末およびモロヘイヤ葉 乾燥粉末添加パンは, 気泡壁が無添加パンに比ベ, 厚い 膜状のものに覆われている様子が観察された。このサツ マイモ葉凍結乾燥粉末添加パンに認められた膜状のもの は，キシロースを多く含むガラクチュロン酸主体の食物 纎維であると考えられた8)。同様にモロへイヤ葉乾燥粉 末添加パンにおいてもラムノース, ガラクトース, グル コースを多く含むガラクチュロン酸主体の食物繊維が膜 を形成しているものと考えられた ${ }^{8)}$ 。また，これらの食 物繊維は粘性を有する水溶性食物繊維であることを確認 している8)。したがって，これらの食物繊維の物理的性 質が組織構造に影響を与えているものと思われた。

4 ）パンの老化 パンは焼成後, 時間経過に従い, 内相部が硬くなり，パサパサした食感を示すようになる。 このような現象はパンの老化と言われるが，これはパン の品質を左右する重要な因子である。パンの老化に影響 を及ぼしている成分は, 水分, デンプン, グルテンで, 特にデンプンの老化が主な原因と考えられている。そこ で, パン中のデンプンの糊化度を BAP 法で測定し, 緑 葉乾燥粉末添加パンの老化状態の把握を行った。結果は 表 3 に示した。

いずれのパンも焼き上がり直後の糊化度は， $65 \%$ 前後 であり,すでに報告されている值とほぼ同程度であっ た20,21)。これを $20^{\circ} \mathrm{C} て ゙ 3$ 日間保存すると， 3 種類のパン とも糊化度は約34\%に低下した。しかし, サッマイモ葉 凍結乾燥粉末およびモロへイヤ葉乾燥粉末添加による影 響は認められなかった。当初, 緑葉乾燥粉末を添加した 食物繊維を含むパンは, 食物緎維の水分保持能力から水 
分含有量の多いパンが製造でき，パンの老化の遅れが観 察される17) と予測したが，そのような現象は認められな かった。これは, パンの水分含量にも違いが認められな かったことからも裏づけされる。

パンの老化は, パンの硬さに現れるのでパン焼成24時 間後の内相部の硬さを測定し, 表 3 に示した。なお, 焼 成直後の測定は, パンが軟弱で, 裁切が不可能であった ため焼成24時間後で比較した。

$60 \%$ 圧縮下での応力は, 無添加パン $5.65 \times 10^{3} \mathrm{~Pa}$, サ ツマイモ葉凍結乾燥粉末添加パン $6.01 \times 10^{3} \mathrm{~Pa}$, モロヘ イヤ葉乾燥粉末添加パン $6.47 \times 10^{3} \mathrm{~Pa}$ であり, 緑葉乾燥 粉末を添加しても応力に顕著な違いは認められなかった。 これは, 官能検査の硬さの評価と同様な結果であった。 パンの老化の面からも, サツマイモ葉凍結乾燥粉末およ びモロヘイヤ葉乾燥粉末添加は, 無添加とほぼ变わりが なく，影響を及ぼさないことがわかった。

\section{要 約}

サツマイモ葉の有効利用の可能性を検討する目的で, これら緑葉乾燥粉末をパンに添加し, その製パン性と品 質について実験を行った。

(1) ファリノグラムでは, 緑葉乾燥粉末を添加すると ミキシングによる安定性が低下することが認められたが， パン生地の膨張力はやや良好であった。したがって, 緑 葉乾燥粉末添加パンを調製する際は, ミキシングを無添 加パンより短くする必要がある。その他の製パン性には 問題はなかった。

(2) サッマイモ葉凍結乾燥粉末をパンに添加しても, その比容積, 水分含有量, デンプンの糊化度およびパン の硬さに対して影響を及ぼさなかった。しかし，色調は モロヘイヤ葉乾燥粉末添加パンに比べ，やや明るさが低 かった。また，分析型官能検査においてもサツマイモ葉 凍結乾燥粉末添加パンは, モロヘイヤ葉乾燥粉末添加パ ンと近似した評価を得た。嗜好型官能検査では, 色のさ え以外, 両者のパンとも無添加パンと有意な差は認めら れなかった。これらの緑葉乾燥粉末を添加したパンの組 織構造では, 食物繊維と思われる膜状のものがグルテン を覆っている様子が観察された。

(3) サツマイモ葉凍結乾燥粉末は食用として利用でき, 新規の素材としてその利用性に期待が持たれた。また， サツマイモ葉凍結乾燥粉末を $2 \%$ 添加したパン $100 \mathrm{~g}$ 中 には, 食物繊維 $2.8 \mathrm{~g}$, カロテン $49 \mu \mathrm{g}$, カルシウム $87 \mathrm{mg}$, ポリフェノール $11 \mathrm{mg}$ が含有され, サツマイモ葉凍結乾
燥粉末の添加によってパンの機能性を向上させる可能性 が示唆された。パンは，毎日食べることもできるため， 機能性成分を毎日容易に揁取できる点でも注目され，健 康の維持・増進に役立つと考えられた。

本研究を行うにあたり, ファリノグラフ測定に便宜を おはかりいただきました共立女子大学教授高橋節子先生, 並びにご指導いただきました武蔵丘短期大学教授永嶋伸 浩先生に厚く御礼申し上げます。

\section{文献}

1）坂本 敏: 熱帯のいも類一サッマイモ・ジャガイモ一, 国際農林業協力協会, 東京, p.48（1987）

2）小林 化: サッマイモのきた道, 古今書院, 東京, p.83 (1984)

3）農業研究センター作物開発部甘しょ育種研究室 : 新品種 決定に関する参考成績書「かんしょ関東109号」, p.1（1996）

4) Ishida, H., Suzuno, H., Sugiyama, N., Innami, S.and Maekawa, A. : Food Chemistry, 68, 359 (2000)

5）山川 理, 吉元 誠: 九農研, 60, 40 (1998)

6）津久井亜紀夫, 鈴木敦子, 小口悦子, 永山スミ : 家政誌, 44, 887 (1993)

7) Innami, S., Tabata, K., Shimizu, J., Kusunoki, K., Ishida, H., Matsuguma, M., Wada, M., Sugiyama, N. and Kondo, M. : Plant Foods for Human Nutrition, 52, 55 (1998)

8）石田 裕, 鈴野弘子, 杉山法子, 印南敏, 和田政裕, 松本信二: 東京農業大学プロジェクト研究研究成果報告, p. 241 (1996)

9）沖 智之, 増田真美, 納美由紀, 小林美緒, 古田 収, 西場洋一, 須田郁夫 : 食科工, 49, 683（2002）

10）奥村晃美，深澤秀夫，渡辺輝夫 : 九農研， 62，148（2000）

11）根角厚司, 武田善行, 山川 理 : 九農研, 60, 42 (1998)

12）石田裕, 鈴野弘子, 印南 敏, 前川昭男, 田所忠弘, 日食保蔵誌，29，75（2003）

13）菅野智栄：食品と科学，38，108（1996）

14) Morita, M., Kang, W. W., Hamauzu, Z. and Sugimoto, Y., J. Appl.Glycosci., 46, 23 (1999)

15）中野淳子, 大羽和子 : 家政誌, 46, 321 (1995)

16）大羽和子, 中野淳子 : 家政誌, 47, 21（1996）

17）田中康夫, 松本 博: 製パンプロセスの科学, 光琳, 東 京, pp.40-255 (1991)

18）貝沼圭二, 松永暁子, 板川正秀, 小林昭一: 澱粉科学, 28, 235 (1981)

19） Sandstedt, R. M. : Baker's Dis., 35, 36 (1961)

20）松永暁子，貝沼圭二：家政誌，34，73（1983）

21）新原立子, 山田啓子: 高知大学教育学部研究報告第 3 部, 44, 1 (1992) 